\title{
Building Interest In Entrepreneurship Through The Expectations Of Income, Family Environment And Education
}

\author{
Hasyim $^{1 *}$, Kafi Puddin ${ }^{2}$, Khairani Alawiyah Matondang ${ }^{3}$ \\ 1,2,3Fakultas Ekonomi Universitas Negeri Medan, Indonesia \\ *mashasyim4@gmail.com
}

\begin{abstract}
This study aims to determine: Effects of Income Expectations, Family Environment, and Entrepreneurship Education on Entrepreneurial Interest of Faculty of Economics, Universitas Negeri Medan. The sampling method was carried out by means of purposive sampling in which the study was not conducted in the entire population, but focused on the target of 105 students. The instrument testing was conducted on 50 students from the Faculty of Economics. Classic assumption tests include normality test, linearity test, multicollinearity test, and heteroscedasticity test. Hypothesis tests used are simple linear regression analysis and multiple linear regression. Data collection techniques using interviews, questionnaires and literature studies and analysis tools used are causality analysis. Based on the research results obtained (1) a significance level of $0.019<0.05$ hypothesis is accepted, this shows the interest of entrepreneurship in students of the Faculty of Economics, Universitas Negeri Medan. (2) significance level of $0.004<0.05$ hypothesis is accepted, this shows that the greater the support of the family will increase the interest of entrepreneurship in students of the Faculty of Economics, Universitas Negeri Medan. (3) the significance level of $0,000<0.05$ hypothesis is accepted, this shows that the higher the level of students' understanding of entrepreneurship will increase the interest in entrepreneurship. (4) significance level of $0,000<0.05$ hypothesis is accepted, this shows that if students have high expectations about entrepreneurial income, students have a good understanding of entrepreneurship and family support there will be an increase in entrepreneurship interest in students of the Faculty of Economics, State University Field.
\end{abstract}

Keywords: Income Expectations, Family Environment, Entrepreneurship Education, Entrepreneurial Interest.

\section{Introduction}

Nowadays people find it difficult to get jobs. This is because the number of jobs is not proportional to the addition of new workers. The number of new workers who have the desire to meet their daily needs is a factor for people to find work. Unfortunately, competition is so tight in job selection and the large number of people competing in jobs makes the number of new workers not accommodated and there are also intellectuals who get less decent jobs. 
Unemployment is a problem that almost happens in every country, including Indonesia. In Indonesia, the highest unemployment rate is actually created by educated groups. The unemployed workforce consists of various educational backgrounds. This is due to the fact that these graduates focus on finding work rather than creating their own jobs.

Unemployment is not the result of a choice not to work, but a result of increasingly difficult to get a job, especially in big cities. Based on data from the Indonesian Central Statistics Agency in 2018, the number of labor force in February 2018 was 133.94 million people, up 2.39 million compared to February 2017. The labor force forming components are the working population and unemployed. In February 2018, 127.07 million people were employed while 6.87 million people were unemployed. This condition will be further exacerbated by global competition that will bring together Indonesian tertiary graduates to compete freely with graduates from foreign tertiary institutions.

Compared to other countries in Southeast Asia (ASEAN), the number of entrepreneurs or entrepreneurs in Indonesia is still very low at under 2\%. As revealed by the Minister of Cooperatives and Small and Medium Enterprises, Anak Agung Gede Ngurah Puspayoga that the number of entrepreneurs in Singapore reached 7\% (of the population), Malaysia 5\%, Thailand 3\%, while in Indonesia the large population is only $1.65 \%$. So, the need for student nurseries to become entrepreneurs and create jobs so that the number of entrepreneurs in Indonesia increases and the unemployment rate can be reduced.

Entrepreneurship is an attempt by someone to create their own jobs either opening a business or creating something new to improve the economy for themselves and for others. Entrepreneurship requires a willingness to take risks with full calculation so that it can overcome obstacles to achieve the expected success.

Entrepreneurial interest can be seen from the willingness to work hard and diligently to achieve business progress, the willingness to bear various risks related to the actions taken, willing to take new paths and ways, willingness to live frugally, willingness to learn. In establishing a business or entrepreneurship, it requires business capital that is used in carrying out business activities.

Income expectation is a person's expectation of income earned from business or work activities. Being an entrepreneur expects high income rather than being a company employee. Someone with higher income expectations than working as an employee is an attraction to be an entrepreneur. Based on the results of preliminary observations, there are still many Office Administration Education students who think that the income from entrepreneurship is still low and uncertain, even though the high and low income derived from entrepreneurship depends on one's efforts in realizing high income.

Family environment is the first environment in a person's life. The family environment consists of parents, relatives and other closest relatives. In the family environment, one of them is parent who will influence their children in determining their future, for example, when it comes to job selection.

Faculty of Economics, Medan State University in its curriculum has included entrepreneurship courses. In addition to entrepreneurship lectures, the Faculty of Economics, Medan State University often holds entrepreneurship seminars. The aim is nothing else so that students have an entrepreneurial mentality and encourage to become real entrepreneurs after they graduate so that the number of entrepreneurs in Indonesia increases and can reduce 
unemployment. Based on the preliminary observations of researchers, only a few Office Administration Education students chose the entrepreneurial profession because their knowledge of entrepreneurship was lacking. This study examines several factors that affect students' interest in entrepreneurship.

The formulation of the problem in scientific papers is intended so that writing is directed and does not extend to other subjects. Sugiyono states that the problem is interpreted as a deviation between what should be and what actually happened. Based on the background of the problems above, the main problems in this study are: How to increase entrepreneurial interest in Office Administration Education Students in Medan State University?

\section{Revenue Expectations}

According to Paulus "Expectation of income is an expectation of obtaining higher income so that with higher income expectations it will further increase interest in entrepreneurship in students". "Revenues are gross inflows of economic benefits arising from an entity's normal activities in a period if the inflows result in an increase in equity, which does not originate from investment contributions". "Revenue is all acceptance of a person in return for his services in the production process. The return of services can be in the form of wages, interest, rent or profit depending on the factors of production involved in the production process "[1]. Meanwhile, according to Wahyu Adji [2], "income is income received by someone from a company in the form of salary, wages, rent, interest and profits including various benefits, such as health benefits or pensions". "Income is income earned by someone in the form of money or goods".

According to Zimmerer, Scarborough and Wilson [3], "being an entrepreneur will get amazing benefits. Entrepreneurship can earn high and unlimited income according to his expectations in order to fulfill all his desires ". The size of the income received from entrepreneurship depends on the work or work done. It is the desire to earn unlimited income that can generate interest in entrepreneurship. "People who work for themselves have a four times greater chance to become rich than people who work for others" [4].

Based on the description, there is a difference in understanding income. In general, income is money received by someone during a certain period in the form of salary, wages, rent, profits, and so on. In accounting, income is income derived from the company's operational activities. Income expectation is someone's expectation of the income received in the form of money or goods to fulfill his life. Expectations or expectations for a better income is one of the factors that influence a person's desire for entrepreneurship. If someone hopes to generate a higher income by becoming an entrepreneur, then he will be increasingly motivated to become an entrepreneur. With entrepreneurship, a person will obtain income from his position as a business owner and income derived from his position as a manager. In this study, researchers used indicators of income expectations including high income and unlimited income. The size of the income received from entrepreneurship depends on the work or work done. It is the desire to earn unlimited income that can generate interest in entrepreneurship. People who work for themselves tend to have greater opportunities to get rich than people who work for others.

\section{Family Environment}

In general, income is money received by someone during a certain period in the form of salary, wages, rent, profits, and so on. Income expectation is someone's expectation of the income 
received in the form of money or goods to fulfill his life. Expectations or expectations for a better income is one of the factors that influence a person's desire for entrepreneurship. If someone hopes to generate a higher income by becoming an entrepreneur, then he will be increasingly motivated to become an entrepreneur.

According to Conny Semiawan "the family environment is the first and foremost medium that influences behavior in child development". The family environment is the smallest group in the community consisting of fathers, mothers, children and other family members. The family environment, especially parents, plays an important role in the development and growth of children. Parents also play a role as directors for the future, meaning indirectly parents can also influence their children's interest in choosing work, including in terms of being an entrepreneur. This is in line with what was delivered by Wasty Soemanto [5] that "parents or family are laying the foundation for children's preparation so that in the future they can become effective workers".

Syamsu Yusuf [6], "the environment is the whole physical / natural or social phenomenon (event, situation, or condition) that influences or is influenced by individual development". "The family is where the main activities of an individual's life take place, so the family becomes the first and foremost institution in the development of human resources" [7]. "In the family social interaction will occur where a child first learns to pay attention to the desires of others, learn to work together, help each other, here children learn to play the role of social beings who have certain norms and skills in association with others" [6]. "In general, the characteristics of a family are the couple relationships in marriage ties, the recognition of the existence of children born, and the existence of economic life in married life".

Buchari [8] revealed that "there is an influence from parents who work alone, and have their own business and have a tendency for their children to become entrepreneurs too". This situation often inspires children from childhood. Children who have parents who are entrepreneurs or live in an entrepreneurial family environment will receive knowledge in the early days so as to form attitudes and perceptions about trust in entrepreneurial abilities.

Based on these descriptions it can be concluded that the family environment is the smallest group in society and is the first environment that influences the development and behavior of children. In the family environment, children get attention, affection, encouragement, guidance and example by parents to be able to develop their potential for future development. The family environment has a very big influence on the development and career / work choices of a child and the influence of parents can be through the parent model and interactions within the family.

Interest in being an entrepreneur is formed when the family provides positive support for their interests. Parents who become entrepreneurs can also arouse their children's interest to become entrepreneurs. For example, parents who have a certain business, then the child will be interested in opening the same business because they see the success of their parents and their parents' encouragement to open the same business. In addition, the mindset of parents influences the interest in entrepreneurship because if parents have embedded the spirit of entrepreneurship and know the importance of entrepreneurship, it will affect their children so that the child wishes to become entrepreneurs. Indicators used in the family environment are parental work and parental support. 


\section{Entrepreneurship Education}

According to Redja Mudyaharjo [9]: Education is a conscious effort made by the family of the community, and the government, through guidance, teaching and training activities that take place in school and outside of lifelong school, to prepare students to be able to play a role in various environments precisely in the future. One's education has an influence on one's knowledge and expertise.

According to Soekidjo Notoatmojo [10], "education is any planned effort to influence other people, whether individuals, groups, or the community so that they do what is expected by education practitioners".

According to Sugihartono, "education is an effort made consciously to change human behavior both individually and in groups to mature humans through teaching and training efforts so that they have the ability to be responsible for all their actions". According to Retno and Trisnadi, "entrepreneurship education is a learning process to change the attitudes and mindsets of students towards choosing an entrepreneurial career". Students who have taken entrepreneurship courses will have intrinsic values and entrepreneurial characteristics that will increase their interest and love for the world of entrepreneurship.

According to Buchori [8], "entrepreneurship education and training is growing rapidly in Europe and the United States both at the level of courses or at the University". Entrepreneurship courses are given in the form of public lectures, or in the form of study program concentrations.

Some of the courses offered have the following objectives:

a. Understand what is the role of companies in the economic system.

b. The advantages and disadvantages of various forms of the company.

c. Know the characteristics and processes of entrepreneurship

d. Understand the product planning and product development process

e. Being able to identify business opportunities and create creativity and form cooperative organizations

f. Able to identify and look for sources

g. Understand the basics of marketing, financial, organization, production

$\mathrm{h}$. Able to lead a business and face future challenges.

Zimmerer, Scarborough and Wilson [3], stated that one of the factors driving the growth of entrepreneurship in a country lies in the role of universities through organizing entrepreneurship education both in lecture activities as well as seminar activities and entrepreneurial practices. The university is responsible for educating and providing entrepreneurial skills to its graduates and providing motivation to dare to choose entrepreneurship as their career.

Based on the description it can be concluded that entrepreneurship education is guidance given by someone to change one's attitude and mindset so that they are interested in becoming entrepreneurs. In addition to entrepreneurship education, entrepreneurship training is needed such as entrepreneurial seminars and entrepreneurial practices because with the seminar inviting successful entrepreneurs will provide a separate motivation for someone to entrepreneurship while entrepreneurial practice will provide experience and can be a driving force for entrepreneurial interest. The high interest in entrepreneurship will increasingly give birth to young entrepreneurs who have creativity and innovation in various fields. 


\section{Entrepreneurial Interest}

Entrepreneurial interest is a sense of interest to become an entrepreneur who is willing to work hard and diligently to achieve business progress. Entrepreneurial interest is not brought from birth but grows and develops according to the influencing factors. "Factors that influence the growth of decisions for entrepreneurship are the result of the interaction of several factors, namely the character of a person's personality and environment" [11].

Entrepreneurial interest consists of two words, namely interest and entrepreneurship. Interest is a feeling of preferability and a sense of attachment to a thing or activity, without anyone asking. Interest is basically the acceptance of a relationship between oneself and an outside self. Slameto [11] states that "interest is a feeling of preferability and a sense of interest in a thing or activity, without anyone asking". Syaiful Bahri Djamarah [12] defines that "interest as a settled tendency to pay attention and remember some activities".

Someone who is interested in the activity will pay attention to the activity consistently with pleasure. Interest is interpreted as the tendency of settled subjects to be interested in a particular field of study or subject and feel happy to study the material [7]. Moment interest is the feeling of being attracted to a topic being discussed or studied for that often the term "attention" ". Attention in the sense of "momentary interest" needs to be distinguished from attention in the sense of "concentration", as explained above. Between interest and feeling happy towards a reciprocal relationship, so it is not surprising that students who feel displeased, will be less interested, and vice versa.

While the Language Center of the Ministry of National Education [13] defines "interest as the tendency of a high heart for something, passion and desire". Agus Sujanto states that "Interest is a concentration of attention that is accidentally born with a full will and depends on talent and environment".

Interest will not be separated from someone's happy feelings about something, because if someone is interested in something, it will pour out all the feelings of pleasure towards something. "Interest in entrepreneurship arises because there is a feeling of pleasure towards entrepreneurial activities, students who have a sense of pleasure and are interested in entrepreneurship will be more passionate and diligent in participating in practical and theoretical activities, so there will be a sense of wanting to master it".

Interest in entrepreneurship can be seen from two main indicators namely how strong a person's efforts to try to do entrepreneurial activities and how much effort someone plans to carry out entrepreneurial activities (such as activities in managing time and finance for entrepreneurial purposes). Yuyus [14], defines "entrepreneur as someone who has the creativity of a new business with courage to bear risks and uncertainties that aim to seek profits and business growth based on identifying opportunities and being able to utilize resources and capitalize on these opportunities". Meanwhile, according to Hendro [15], "entrepreneurship is the ability that exists in a person so that it can be utilized optimally so that it can improve living standards".

According to Kasmir [16], "entrepreneurs are people who are brave in taking risks to open businesses in various opportunities". Having the courage to take risks means to be mentally independent and dare to start a business, without being overwhelmed by fear or anxiety even in uncertain conditions. Joseph Schhumper in Buchori [8], defines "entrepreneurship is a person who breaks down the existing economic system by introducing new goods or services, by creating new 
forms of organization or processing new raw materials". In terms of characteristics, entrepreneurs are those who establish, manage, develop, and institutionalize their own companies. Entrepreneurship involves two main elements, namely opportunities and the ability to respond to opportunities. Thus "entrepreneurship is a response to business opportunities that are revealed in a set of actions and produce results in the form of business organizations that are institutionalized, productive, and innovative" [14].

Factors that encourage interest in entrepreneurship according to Bygrave [8]:

a. Personal factors, concerning aspects of personality, among others, the existence of dissatisfaction with one's work, the existence of termination of employment, no other work, encouragement due to the age factor, the courage to bear the risk, and high commitment / interest in the business

b. Environmental factors, concerning relationships with the physical environment include, the existence of competition in the living world, the existence of resources that can be utilized such as capital, savings, inheritance, buildings, and strategic locations, Following business training courses or business incubators, and government policy, the availability of facilities business location, credit facilities and business guidance.

c. Sociological factors, concerning relationships with family and so on: There are relationships or relationships for others, There is a team that can be invited to work together in trying, There is encouragement from parents to open a business, the existence of family assistance in a variety of ease and the existence of previous business experience

Based on this description, it can be concluded that the interest in entrepreneurship is not always carried from birth, but can be grown with education and training. Interest is a sense of interest in a thing or activity and feels happy doing it. The sense of attraction is not because of coercion but because of a high desire to achieve its goals. Interest is basically the acceptance of a relationship between oneself and something outside of itself. The stronger the relationship, the greater the interest.

Entrepreneurship is the process of creating a creative and innovative business by utilizing existing opportunities to improve living standards and be useful for the community. Entrepreneurial interest is a sense of interest in entrepreneurial activities that create a business that benefits themselves and the surrounding environment. Entrepreneurial interest is influenced by the existence of high soft skills because being an entrepreneur requires a variety of skills and strong personal character.

Entrepreneurship will make a person not dependent on others because being an entrepreneur has the freedom to achieve the goals of his dreams. This freedom can be in the form of freely determining the desired business, free to set operational schedules, and of course free to determine the desired profit. Freedom is what will make someone interested or interested in becoming an entrepreneur. In addition, being able to assist the government in overcoming unemployment is due to the creation of new jobs that can accommodate prospective workers. This will benefit the community, especially the communities where businesses are established. Factors affecting entrepreneurial interest are high income expectations, support from the family environment and received entrepreneurship education. The indicators used include not being dependent on others, helping the social environment and feeling like being an entrepreneur. 


\section{Research Method}

This research was conducted at the Faculty of Economics, Universitas Negeri Medan in the even semester of 2019. This type of research used in this study is comparative causal research. Comparative causal research is a type of research with the characteristics of problems in the form of a causal relationship between two or more variables. The population of this research is the students of Office Administration Study Program Medan State University class of 2015. The population of Office Administration students of the Faculty of Economics, Medan State University class of 2015 is 101 students where class A has 55 students and class B has 46 students. The number of samples used was 50 respondents with snowball sampling technique. The hypotheses proposed in this study are as follows:

$\mathrm{H}_{1}$ : The higher the student's expectations for income generated from entrepreneurship, the higher the student's interest in entrepreneurship will be.

$\mathrm{H}_{2}$ : The greater the family's support, the greater their children's interest in entrepreneurship.

$\mathrm{H}_{3}$ : The higher the level of students' understanding of entrepreneurship, the higher the student's interest in entrepreneurship will be.

$\mathrm{H}_{4}$ : Simultaneous income expectations, family environment and entrepreneurship education have a significant effect on interest in entrepreneurship.

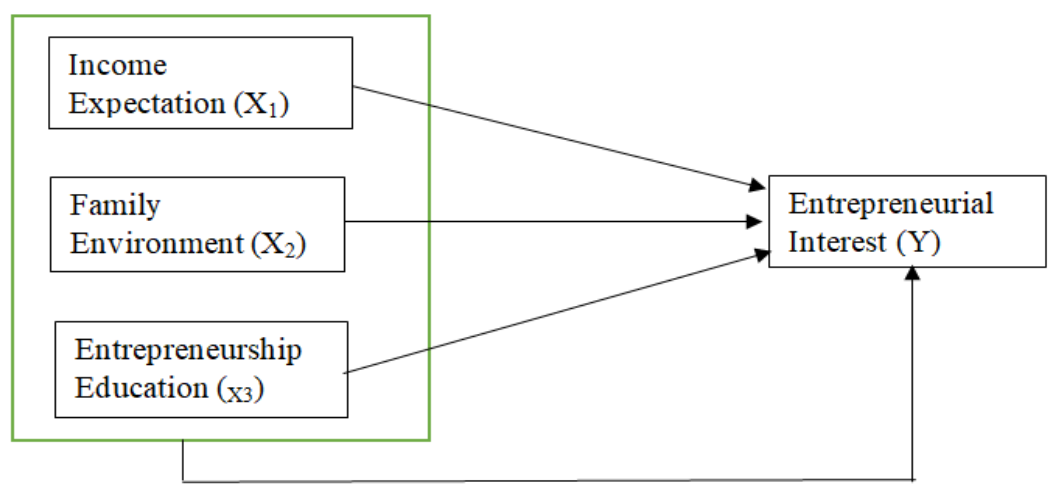

Fig. 1 Conceptual Framework

The purpose of this study is to prove and analyze the influence of income expectations, family environment and entrepreneurship education on entrepreneurial interest. Based on the purpose of the study, this research is classified as an explanatory research (explanatory research), which is a research that aims to explain the position of the variables studied and the relationship between one variable and another. The population in this study were all students of the Faculty of Economics, Office Administration Department at Medan State University class of 2015 who had participated in entrepreneurship courses totaling 101 students. The number of samples used was 50 respondents with snowball sampling technique. 


\section{Data Analysis}

To find out or measure the intensity of the relationship between the dependent variable (Y) with several independent variables $(\mathrm{X})$, the type of analysis used is multiple regression analysis [17]. To test the hypothesis, the $\mathrm{T}$ test is used to test how far the influence of one independent variable individually in explaining the variation of the dependent variable [17]. The test is based on the results of the significance value of 0.05 or $\alpha=5 \%$. And $\mathrm{F}$ test to determine the effect of independent variables namely work experience, work performance, work discipline jointly influence the promotion variable as the dependent variable [17]. The test is based on the results of the significance value of 0.05 or $\alpha=5 \%$.

The coefficient of determination (R2) essentially measures the effect of the independent variable on the dependent variable. The coefficient of determination is between zero and one. A small R2 value means that the ability of independent variables to explain the dependent variable is very limited. A value close to one means that the independent variables provide almost all the information needed to predict the variation of the dependent variable.

\section{Results and Discussion}

\subsection{Analysis of Multiple Linear Regression}

Regression analysis is used to test hypotheses about the effect of partially independent variables on the dependent variable. Based on the estimation of multiple linear regression with the IBM SPSS program, the following results are obtained:

Table 1. Results of Multiple Linear Regression Analysis

\begin{tabular}{cc}
\hline Independent Variable & $\begin{array}{c}\text { Unstandardized } \\
\text { Coefficients } \boldsymbol{B}\end{array}$ \\
\hline (constant) & 0.794 \\
Income Expectation (X1) & 0.263 \\
Family Environment (X2) & 0.303 \\
Entrepreneurship Education (X3) & 0.470 \\
\hline Source: Data Process Results with IBM
\end{tabular}

Source: Data Process Results with IBM

Based on Table 4.1, the regression equation in this study is as follows:

$$
\mathrm{Y}=0,794+0,263 \mathrm{X} 1+0,303 \mathrm{X} 2+0,470 \mathrm{X} 3
$$

Information:

$\mathrm{Y}=$ Entrepreneurial Interest

$\mathrm{X} 1=$ Revenue Expectations

$\mathrm{X} 2$ = Family Environment

$\mathrm{X} 3$ = Entrepreneurship Education 
The regression equation above can be interpreted as follows:

i. A constant of 0.794 shows the amount of interest in entrepreneurship when income expectations, family environment and entrepreneurship education are zero.

ii. $\quad \mathrm{b} 1=0.263$ indicates that if income expectations increase by 1 unit the interest in entrepreneurship will increase by 0.263 units, and vice versa, assuming the family environment and entrepreneurship education are constant.

iii. $\quad \mathrm{b} 2=0.303$ indicates that if the family environment increases by 1 unit, the interest in entrepreneurship will increase by 0.303 units, and vice versa, assuming income expectations and entrepreneurship education are constant.

iv. $\quad b 3=0.470$ indicates that if entrepreneurship education increases by 1 unit, the interest in entrepreneurship will increase by 0.470 units, and vice versa, assuming income expectations and the family environment are constant.

\subsection{T-test}

Hypothesis 1 in this study was tested for truth by using partial tests. Testing is done by looking at the significance level ( $\mathrm{p}$-value), if the significance level resulting from calculations below 0.05 then the hypothesis is accepted, conversely if the significance level of the calculated results is greater than 0.05 then the hypothesis is rejected.

Table 2. T-Test Results

\begin{tabular}{|c|c|c|c|c|c|}
\hline No & Variable & $\begin{array}{l}\text { Sig. } \\
\text { Count }\end{array}$ & & $\begin{array}{c}\text { Level of } \\
\text { Significance }\end{array}$ & Information \\
\hline 1 & Income Expectation & 0,001 & $<$ & 0,05 & Significance \\
\hline 2 & Family Environment & 0,000 & $<$ & 0,05 & Significance \\
\hline 3 & Entrepreneurship Education, & 0,003 & $<$ & 0,05 & Significance \\
\hline
\end{tabular}

Source: Data Process Results with IBM SPSS

From table 4.2, it is known that the comparison between the significance level with the significance of the table is as follows:

i. Partial test results show that income expectations have a significance value of 0.019 and less than 0.05 so that income expectations have a significant effect on the interest in entrepreneurship received. It also shows that income expectations affect entrepreneurial interest, which means that the higher income expectations will have an impact on increasing entrepreneurial interest.

ii. The results of the family environment test have a significance value of 0.004 and less than 0.05 so the family environment hypothesis has a significant influence on the interest in entrepreneurship. This also shows that the family environment influences interest in entrepreneurship, which means the greater family support that is given will have an impact on increasing entrepreneurial interest. 
iii. Partial test results show that entrepreneurship education has a significance value of 0,000 smaller than 0.05 so that the entrepreneurship education hypothesis has a significant effect on the interest in entrepreneurship. It also shows that entrepreneurship education affects the interest of entrepreneurship, which means that the higher the level of student understanding of entrepreneurship will have an impact on increasing interest in entrepreneurship.

\section{$3.3 \quad$ F-Test}

To test the effect of the independent variables jointly tested using the $F$ test.

Table 3. F Test Results

\begin{tabular}{|c|c|c|}
\hline $\begin{array}{c}\text { Sig. } \\
\text { Count }\end{array}$ & $\begin{array}{c}\text { Level of } \\
\text { Significance }\end{array}$ & Information \\
\hline 0,000 & 0,05 & Significance \\
\hline
\end{tabular}

Source: Data Process Results with IBM SPSS

The results of the statistical calculations in table 4.3 show the significance value count $=$ 0,000 . By using a significance level of 0.05 , the significance of the calculation is smaller than the significance level, it can be concluded that simultaneous income expectations, family environment and entrepreneurship education influence the interest in entrepreneurship.

\subsection{Coefficient of Determination (R2)}

The coefficient of determination is a quantity that indicates the amount of variation in the dependent variable that can be explained by the independent variable. In other words, the coefficient of determination is used to measure how far the independent variables are in explaining the dependent variable.

Table 4. Determination Coefficient Test Results (R2)

\begin{tabular}{clc}
\hline No & \multicolumn{1}{c}{ Criteria } & Coefficient \\
\hline 1 & $R$ & 0,859 \\
2 & $R$ Square & 0,820 \\
3 & Adjusted $R$ Square & 0,817 \\
\hline \multicolumn{2}{c}{ Source: Data Process Results with IBM SPSS }
\end{tabular}

The SPSS output results show the Adjusted R Square value of 0.857. This shows that $85.7 \%$ of entrepreneurial interest in students of the Faculty of Economics, Unmuh Jember is influenced by income expectations, family environment and entrepreneurship education. While the remaining $14.3 \%$ is influenced by other variables outside the model or equation, such as psychology, lifestyle and others.

\section{Discussion}


Based on the test results statistically it can be clearly seen that partially, all independent variables affect the dependent variable. The influence given by the four independent variables is positive, meaning that the higher the income expectations, family environment and entrepreneurship education, the interest in entrepreneurship will increase. These results are consistent with the proposed hypothesis. The results of this study are also in accordance with the results of previous studies. The explanation of each variable effect is explained as follows:

a. The results of hypothesis testing have proven that there is a significant influence of income expectations on entrepreneurial interest. Through the results of calculations that have been made obtained a significance level of 0.019 smaller than 0.05 which means the hypothesis is accepted. This statistical test proves that the higher the expectations of student income will further increase the interest in entrepreneurship in students of Office Administration Education Medan State University. This result is also supported by research conducted by Suhartini [18] which proves that income has a significant positive effect on student interest in entrepreneurship.

b. The results of hypothesis testing have proven that there is a significant influence of the family environment on entrepreneurial interest. Through the calculation results that have been done obtained a significance level of 0.004 and smaller than 0.05 which means the hypothesis is accepted. This statistical test proves that the greater the support of the family will increase the interest in entrepreneurship in Office Administration Education Medan State University. These results support previous research by Putra [19] and Suhartini [18] which show that the family environment has a significant positive effect on student entrepreneurial interest.

c. The results of hypothesis testing have proven the influence of entrepreneurship education on entrepreneurial interest. Through the results of calculations that have been made obtained a significance level of 0,000 and smaller than 0.05 which means the hypothesis is accepted. This statistical test proves that the higher the level of students' understanding of entrepreneurship will increase the interest of entrepreneurship in students at the Medan State University Office of Administrative Education. The results of this study support previous research, namely research conducted by Hermina, et al and Suhartini [18] which prove that entrepreneurship education has a significant positive effect on student interest in entrepreneurship.

d. The results of hypothesis testing have proven there is a significant effect of simultaneous income expectations, family environment and entrepreneurship education on entrepreneurial interest. Through the results of calculations that have been made obtained a significance level of 0,000 and smaller than 0.05 which means the hypothesis is accepted. This statistical test proves that if students have high expectations about income earned by entrepreneurship, where students have a good understanding of entrepreneurship and the family provides support, it will lead to an increase in entrepreneurship interest in students at the Medan State University Office of Administrative Education. 


\section{Conclusions and Suggestions}

\section{Conclusion}

drawn:

From the statistical tests that have been carried out, the following conclusions can be

a. Hypothesis Testing Results have proven that there is a positive and significant effect on income expectations on interest in entrepreneurship partially. This means that the higher income expectations will have an impact on the increasing interest in entrepreneurship.

b. Hypothesis Testing Results have proven that there is a positive and significant influence of the family environment on the interest in entrepreneurship partially. This means that the greater support given by the family will have an impact on the increasing interest in entrepreneurship.

c. Hypothesis Testing Results have proven that there is a positive and significant influence on entrepreneurship education on the interest in entrepreneurship partially. This means more students understanding about entrepreneurship will have an impact on the increasing interest in entrepreneurship.

d. Hypothesis Testing Results have proven there is a positive and significant effect on income expectations, family environment and sales entrepreneurship education on the interests of entrepreneurship simultaneously. This means that the better income expectations, family environment and entrepreneurship education will have an impact on the increasing interest in entrepreneurship.

\section{Suggestions}

Based on the results of the study there are several suggestions that can be given to interested parties. These suggestions are as follows:

a. For Other Researchers

Referring to the limitations of the study, suggestions that can be given include: The next researcher is expected to increase the number of respondents so that the results of the study can be more accurate or represent the population, and the researcher can then add or replace the independent variables in this study with other variables considered also has an influence on purchasing decisions.

b. For the University

Policy holders such as the Dean of the Faculty of Economics, heads of departments, as well as lecturers in entrepreneurship courses need to improve student entrepreneurship competencies through courses and ongoing workshop programs. In addition, the university can also provide a forum in the form of organizations or Student Activity Units (UKM) for business students to continuously share about entrepreneurial experiences so as to create connections between business students.

\section{References}

[1] Yuliana Sudremi. Pengetahuan Sosial Ekonomi kelas X. Jakarta: Bumi Aksara (2017).

[2] Wahyu Adji. Ekonomi SMK Untuk Kelas XI. Bandung: Ganeca Exacta (2014). 
[3] Zimmerer, Thomas W., dkk. Kewirausahaan dan Manajemen Usaha Kecil. Jakarta: Salemba Empat (2015).

[4] Serian Wijayanto. Pengantar Entrepreneursip. Jakarta: Grasindo (2016).

[5] Wasty Soemanto. Pendidikan Wirausaha. Jakarta: PT. Bumi Aksara (2018).

[6] Syamsu Yusuf. Perkembangan Peserta Didik. Jakarta: Raja Grafindo Persada (2016).

[7] W.S. Winkel. Psikologi Pengajaran. Jakarta: Grasindo (2014).

[8] Buchori Alma. Kewirausahaan. Bandung: Alfabeta (2014).

[9] Redja Mudyaharjo. Pengantar Pendidikan. Jakarta: PT. Rajagrafindo Persada (2015).

[10] Soekidjo Notoatmodjo. Pendidikan dan Perilaku Kesehatan. Jakarta: Rineka Cipta (2013).

[11] Slameto. Belajar dan Faktor-Faktor yang Mempengaruhinya. Jakarta: Rineka Cipta (2010).

[12] Syaiful Bahri Djamarah. Psikologi Belajar. Jakarta: Rineka Cipta (2018).

[13] Pusat Bahasa Departemen Pendidikan Nasional. Kamus Besar Bahhasa Indonesia. Jakarta: Balai Pustaka (2006).

[14] Yuyus Suryana. Kewirausahaan. Jakarta: Kencana (2013).

[15] Hendro. Dasar-Dasar Kewirausahaan. Jakarta: Erlangga (2015).

[16] Kasmir. Kewirausahaan. Jakarta: PT. Raja Grafindo Persada Leonardus (2017).

[17] Imam Ghozali. Aplikasi Analisis Multivariate Dengan Program IBM SPSS19. Edisi 5. Semarang: Badan Penerbit Universitas Diponegoro (2016).

[18] Yati Suhartini. "Analisis Faktor-Faktor Yang Mempengaruhi Minat Mahasiswa Dalam Berwirausaha". Jurnal Universitas PGRI Yogyakarta (2016).

[19] Rano Aditia Putra. "Faktor-Faktor Penentu Minat Mahasiswa Manajemen Untuk Berwirausaha". Jurnal Universitas Negeri Padang (2014).

[20] BPS. "Pengangguran Terbuka Menurut Pendidikan Tertinggi yang Ditamatkan 2004 -2014". Diambil dari http://www.bps.go.id/linkTabelStatis/view/id/972 pada tanggal 25 maret 2015.

[21] Gendro Wiyono. Merancang Penelitian Bisnis: SPSS 17.0 \& SmartPLS 2.0. Yogyakarta: STIM YKPN (2014).

[22] Hasyim and Y. Sugiarto, Marketing Architectural Capability and Competitive Networking in Indonesia Fashion Small and Medium Sized Enterprises. Quality - Access to Success, Journal Management Systems, 6 Issue per Year Vol. 19,No. 166 - October 2018, pp 64 - 67, (2018).

[23] Hasyim, et all, Isolating Mecanism as a Mean to Improve Performance of SMEs, European Research Studies Journal Vol. XX, Issue 3A, pp. 594 - 612, (2017).

[24] Mahmud, Aryanto V.D.W., Hasyim, The Effect of Inovation Capability and New Product Development on Marketing Performances of Batik SMEs, Polish Journal of Management Studies, Vol. 15, No. 2, pp 132 - 141, (2017). 
[25] Saiman. Kewirausahaan, Teori, Praktik, dan Kasus-kasus. Jakarta: Salemba Empat (2016).

[26] Suharsimi Arikunto. Manajemen Penelitian. Jakarta: Rineka Cipta (2014).

[27] Suharyadi, dkk. Kewirausahaan. Jakarta: Salemba Empat

[28] Sutrisno Hadi (2004). Analisis Regresi. Yogyakarta: Andi Offset (2017).

[29] Wiji Nurhayat. "Di ASEAN, Persentase Jumlah Pengusaha di RI” (2015). 